\title{
Mesoclemmys tuberculata (Luederwaldt 1926) - Tuberculate Toad-headed Turtle
}

\author{
Daniel O. Santana ${ }^{1}$, Thiago S. Marques ${ }^{2}$, Gustavo H.C. Vieira ${ }^{1}$, \\ Geraldo J.B. Moura ${ }^{3}$, Renato G. Faria ${ }^{4}$, and Daniel O. Mesquita ${ }^{1}$ \\ ${ }^{1}$ Programa de Pós-Graduação em Ciências Biológicas (Zoologia), Universidade Federal da Paraíba, \\ Cidade Universitária, Campus I, CEP 58059-900, João Pessoa, Paraíba, Brazil \\ [danielbioufs@yahoo.com.br; ghcvieira@dse.ufpb.br;danmesq@dse.ufpb.br]; \\ ${ }^{2}$ Laboratório de Ecologia Isotópica, Centro de Energia Nuclear na Agricultura, Universidade de São Paulo, \\ C.P.96, 13416-000, Piracicaba, São Paulo,Brazil [thiagomq@yahoo.com.br]; \\ ${ }^{3}$ Laboratório de Estudos Herpetológicos e Paleoherpetológicos, Departamento de Biologia, \\ Universidade Federal Rural de Pernambuco, Rua Morais Rego, s/n, Dois Irmãos, \\ CEP 52171-900, Recife, Pernambuco,Brazil [geraldojbm@yahoo.com.br]; \\ ${ }^{4}$ Programa de Pós-Graduação em Ecologia e Conservação, Universidade Federal de Sergipe, \\ Cidade Universitária Prof. José Aloísio de Campos, \\ CEP 49100-000 São Cristóvão, Sergipe, Brazil [renatogfaria@gmail.com]
}

Summary. - The Tuberculate Toad-headed Turtle, Mesoclemmys tuberculata (Family Chelidae), is a medium-sized freshwater turtle (carapace length up to 250-300 mm) endemic to Brazil, ranging from the northeastern semi-arid region to the Atlantic-Northeastern basin. This species is usually associated with Caatinga and Atlantic Forest areas, and strongly associated with the basin of Rio São Francisco. Most aspects of $M$. tuberculata ecology remain unknown. Sexual dimorphism is prominent, with adult females larger than males. Reproductive parameters such as mean female size, mean clutch size and mass, egg size, volume and mass, incubation time, reproductive season, and nest site description are unknown for wild populations. Diet composition and feeding behavior are poorly known for wild $M$. tuberculata, but it has been noted that the species is carnivorous and consumes earthworms, fish, molluscs, freshwater shrimp, and insects. The species can often be found associated with anthropogenic environments, such as ponds, which can harbor small populations. Mesoclemmys tuberculata is not currently felt to be threatened, but the lack of population status and life history data for the species are relative limitations to proposing potential conservation measures.

Distribution. - Brazil. Restricted to northeastern Brazil (Alagoas, Bahia, Ceará, Maranhão, Paraíba, Pernambuco, Piauí, Sergipe) with an apparently disjunct population in northern Minas Gerais.

Synonymy. - Rhinemys tuberculata Luederwaldt 1926, Batrachemys tuberculata, Phrynops (Batrachemys) tuberculata, Phrynops tuberculata, Phrynops (Batrachemys) tuberculatus, Phrynops tuberculatus, Phrynops tuberculatus tuberculatus, Mesoclemmys tuberculata.

SubSPECIES. - None recognized.

STATUS. - IUCN 2015 Red List: Not Listed (Least Concern, LC, assessed 1996); TFTSG Draft Red List: Data Deficient (DD, assessed 2011); CITES: Not Listed; Brazil: Least Concern.

Taxonomy. - Mesoclemmys tuberculata was originally described by Luederwaldt(1926) as Rhinemys tuberculata, based on specimens collected in Villa Nova (currently known as Senhor do Bonfim), Bahia, and in Fortaleza, Ceará, northeastern Brazil. Fróes (1957), based on morphological characters, renamed the taxon as Batrachemys tuberculata, and expanded its known distribution in northern and eastern Brazil. Later, Batrachemys tuberculata was referred to Phrynops tuberculatus by Mertens (1970). For many years the genus was referred to as either Phrynops or Batrachemys (Zangerl and Medem 1958; Mertens 1970; Bour 1973; Freiberg 1981; Bour and Pauler 1987; King and Burke 1989). McCord et al. (2001) conducted a study on the broad genus Phrynops and suggested the resurrection of the genus Batrachemys, redesignating the species as Batrachemys tuberculata. However, their analyses were not generally accepted (Rodrigues 2003; Bour and Zaher 2005; TTWG 2011; Costa and Bérnils 2014), mainly due to the lack of resolution within the phylogenetic relationships of South American chelids, and the species has since been placed in the broader genus Mesoclemmys, a former subgenus of Phrynops (Bour and Zaher 2005). Mesoclem$m y s$ currently includes the following species: $M$. dahli, $M$. gibba, M. heliostemma, M. hogei, M. nasuta, M.perplexa, $M$. raniceps, $M$. tuberculata, $M$. vanderhaegei, and $M$. zuliae. 


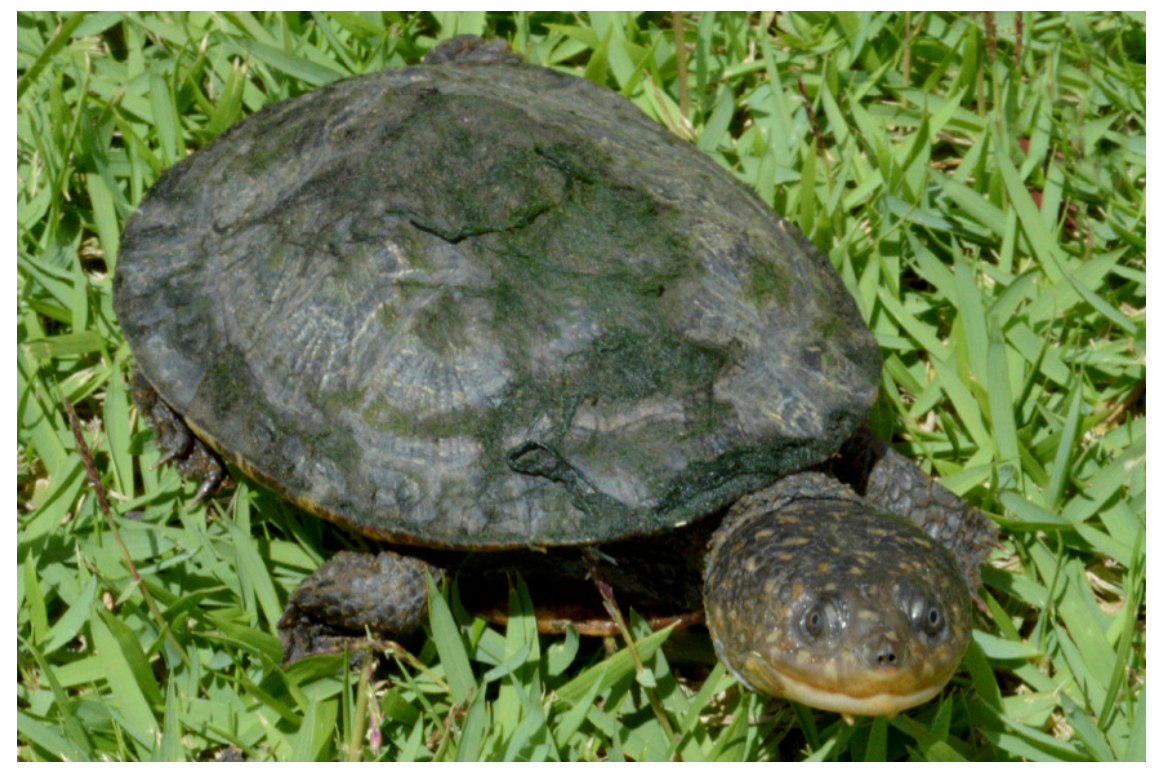

Figure 1. Mesoclemmys tuberculata from Areia Branca, Sergipe, Brazil. Photo by Daniel O. Santana.

Description. - Mesoclemmys tuberculata is a mediumsized species that may reach 250 to $300 \mathrm{~mm}$ in straight carapace length (CL) (Vanzolini et al. 1980; Ernst and Barbour 1989; Vetter 2005). A maximum CL of $235 \mathrm{~mm}$ was recorded for a female in captivity at the São Paulo Zoo (McCord et al. 2001).

The color of the carapace may vary from light to dark brown or can be entirely black. The surface of each scute may be roughened with raised striations (Ernst and Barbour 1989; Bonin et al. 2006). The plastron is yellowish and can present blackish spots, becoming completely dark with ontogeny (Bonin et al. 2006). The head and the neck have a completely dark gray back, and the ventral region is yellowish or grayish. The back of the head can be sprinkled with light dots, and the jaws are light yellow with a lighter stripe on the upper region (Vanzolini et al. 1980; Ernst and Barbour 1989; Bonin et al. 2006). The neck is covered with conical tubercles, a characteristic reflected by the species' name (Ernst and Barbour 1989; Bonin et al. 2006).
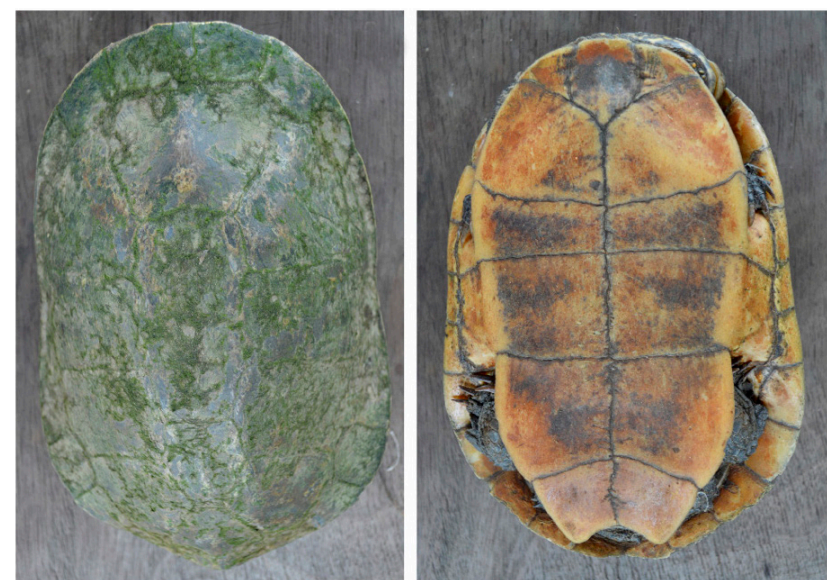

Figure 2. Mesoclemmys tuberculata from Areia Branca, Sergipe, Brazil. Photos by Daniel O. Santana.
Sexual dimorphism is marked, with adult females (mean $\mathrm{CL}=207 \pm 17 \mathrm{~mm}$, maximum $\mathrm{CL}=235 \mathrm{~mm}, \mathrm{n}=$ 13) reaching larger body sizes than males (mean $\mathrm{CL}=182$ $\pm 8 \mathrm{~mm}$, maximum $\mathrm{CL}=190 \mathrm{~mm}, \mathrm{n}=5)$. Females also have deeper shells (carapace height; $\mathrm{CH})($ mean $\mathrm{CH}=73 \pm$ $7 \mathrm{~mm}$, maximum $\mathrm{CH}=85 \mathrm{~mm}, \mathrm{n}=13$ ) than males (mean $\mathrm{CH}=64 \pm 3 \mathrm{~mm}$, maximum $\mathrm{CH}=67 \mathrm{~mm}, \mathrm{n}=5$ ). Males have longer and thicker tails, with a more distal cloacal opening (Corazza and Molina 2004a). Several species of Testudines exhibit sexual dimorphism (Berry and Shine 1980; Gibbons and Lovich 1990; Bujes 2010) as do many Chelidae, including Hydromedusa maximiliani (Souza and Martins 2009), Hydromedusa tectifera (Chinen et al.2004), Acanthochelys macrocephala (Métrailler 2006), Mesoclemmys vanderhaegei (Marques et al.2014), and Mesoclemmys dahli (Forero-Medina et al. 2013).

Hatchling M. tuberculata present morphological aspects and a color pattern that differ greatly from adults. The carapace is oval, with a poorly developed median keel on the second, third, and fourth vertebral scutes. The color of the carapace is dark brown, with gray and black spots, and an orange border. The plastron is mostly orange with a wide central black symmetrical patch, extending from the humeral to the femoral scutes, and extending over the intergular scute. Orange is the predominant color on the plastron bridges and ventral surfaces of the marginal scutes (Santana et al. 2015).

Distribution. - Mesoclemmys tuberculata is a freshwater turtle endemic to Brazil (Moura et al.2014) ranging from the northeastern semi-arid region to the Atlantic-Northeastern basin (Vanzolini et al. 1980; Iverson 1992). It inhabits water bodies in the Brazilian states of Bahia (Santos et al. 2008), Sergipe (Morato et al. 2011), Alagoas (Santos et al. 2008; Lins et al. 2015), Piauí (Loebmann et al. 2006; Cavalcanti 
et al. 2014), Ceará (Loebmann and Haddad, 2010; Moura et al.2015), Maranhão (Batistella et al. 2008; Barreto et al. 2010), Paraíba (Barbosa et al. 2007), Pernambuco (Miranda and Santos, 2008; Moura et al. 2011), Rio Grande do Norte (Caldas et al. 2016), and an apparently disjunct population in northern Minas Gerais (Silveira and Valinhas 2010). This species is usually associated with Caatinga and Atlantic Forest areas, strongly associated with the basin of Rio São Francisco (Batistella et al. 2008; Santos et al. 2008; Loebmann and Haddad 2010; Moura 2010; Morato et al. 2011; Moura et al. 2011, 2014). Recently, it was also recorded from the Cerrado biome in northern Minas Gerais (Silveira and Valinhas 2010).

Habitat and Ecology. - Mesoclemmys tuberculata is associated with coastal ecosystems and semiarid regions, where it is able to use a wide array of habitat types, such as rivers, permanent lakes, and temporal streams (Vanzolini et al. 1980; Loebmann et al. 2006; Silveira and Valinhas 2010; Moura et al. 2012), preferring slow-moving waters (Bonin et al. 2006). The natural habitats identified for the species are the open formations in the semiarid Caatinga region and the Atlantic rainforest of northeastern Brazil (Souza 2005).

Most aspects of M.tuberculata ecology remain unknown (Souza 2004). In the last decade, few studies have focused on the ecology and biology of the species; instead, most have focused on its distributional extent (Loebmann et al. 2006; Santos et al. 2008; Batistella et al. 2008; Loebmann and Haddad 2010; Moura 2010; Silveira and Valinhas 2010; Moura et al. 2011, 2014; Morato et al. 2011; Cavalcanti et al. 2014), hatchling morphology (Santana et al. 2015), and demography and sex ratio at one locality in the Araripe Bioregion (Moura et al. 2015).

Mesoclemmys tuberculata often migrates between water bodies during summer nights (Vanzolini et al. 1980). The ability to migrate between aquatic habitats or even between distinct watersheds is a common feature in chelids, such as Mesoclemmys spp. (Brito et al. 2012), Acanthochelys spixii,

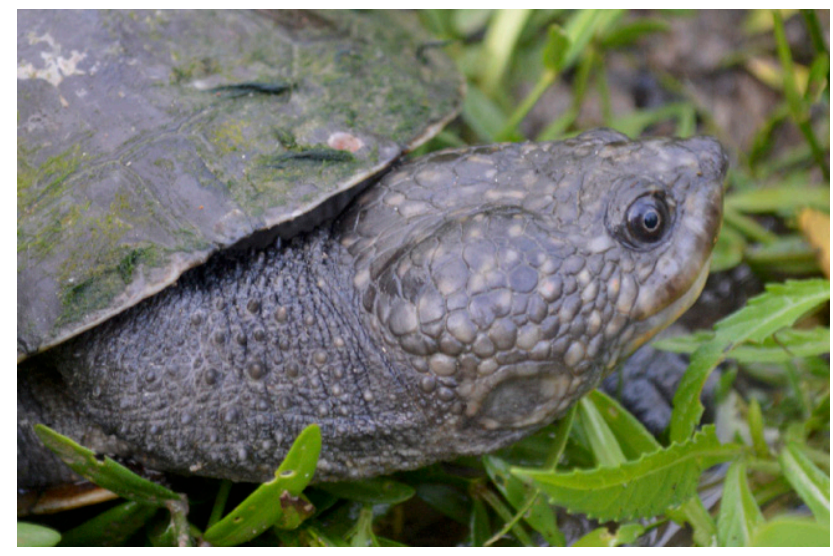

Figure 3. Mesoclemmys tuberculata from Tobias Barreto, Sergipe, Brazil. Photo by Daniel O. Santana. and A. macrocephala (Vinke and Vinke 2008). Migration usually occurs when resources become scarce in their habitats (Kramer 1995; Milan and Melvin 2001).

Moura et al. (2015) documented population density of M. tuberculata in a natural environment, recording a density of approximately 2 turtles/ha, but only a small number of females were recorded in their study. The species can often be found associated with anthropogenic environments, such as ponds, which can harbor small populations of the species (Santana, unpubl. data).

Courtship behavior of $M$. tuberculata has been observed in captivity between January and October, but more frequently between January and July (Corazza and Molina 2004b), with the initial sequence appearing to be similar to those previously reported for other chelids, such as Phrynops geoffroanus (Molina 1996),Hydromedusa maximiliani (Novelli and Souza 2007), and Mesoclemmys vanderhaegei (Brito et al. 2009). The animals were observed mainly in the water, where the male examined the cloacal region, tail, and carapace of the female and tried to bite her neck region. Interactions were also observed on land, with the animals facing each other while the male was biting or trying to bite (feebly) the female's neck and presenting rhythmic head movements. The male was then observed mounting the female, with hindfeet flat on the ground and forefeet placed on her costal scutes (Corazza and Molina 2004b).

Reproductive parameters, such as mean female size, clutch size, egg size, volume and mass, mean clutch mass, incubation time, reproductive season and nest site description are unknown for wild populations (Souza et al. 2006). The only record of nesting occurred in October, in captivity; a single egg dropped in water had a calcareous shell, was smooth and cream-colored, and slightly elongated in shape $(31.6 \times 29.0 \mathrm{~mm})$ and weighed $11.5 \mathrm{~g}$ (Corazza and Molina 2004b). Nest depredation of M. tuberculata by the lizard Salvator merianae has been noted in a remnant of Atlantic forest at the Ecological Station Tapacurá,Pernambuco, Brazil (Moura, unpubl. data).
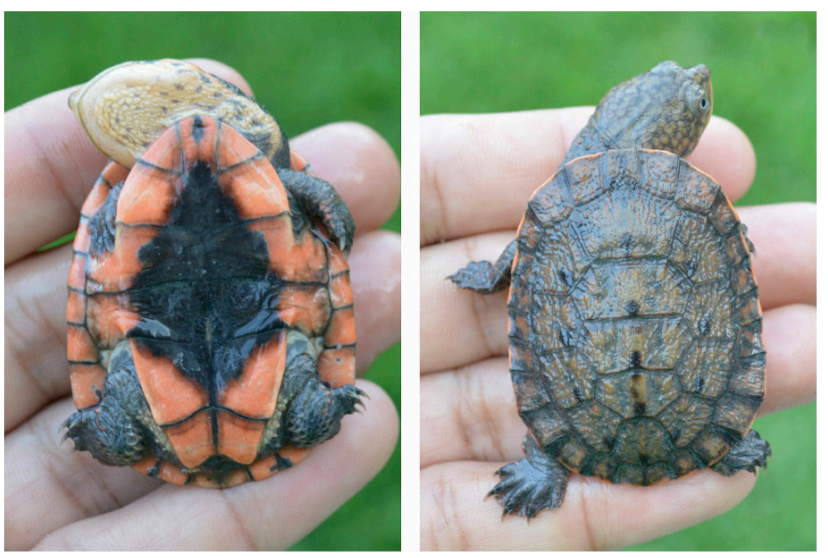

Figure 4. Hatchling Mesoclemmys tuberculata from Itabaiana, Sergipe, Brazil. Photos by Daniel O. Santana. 


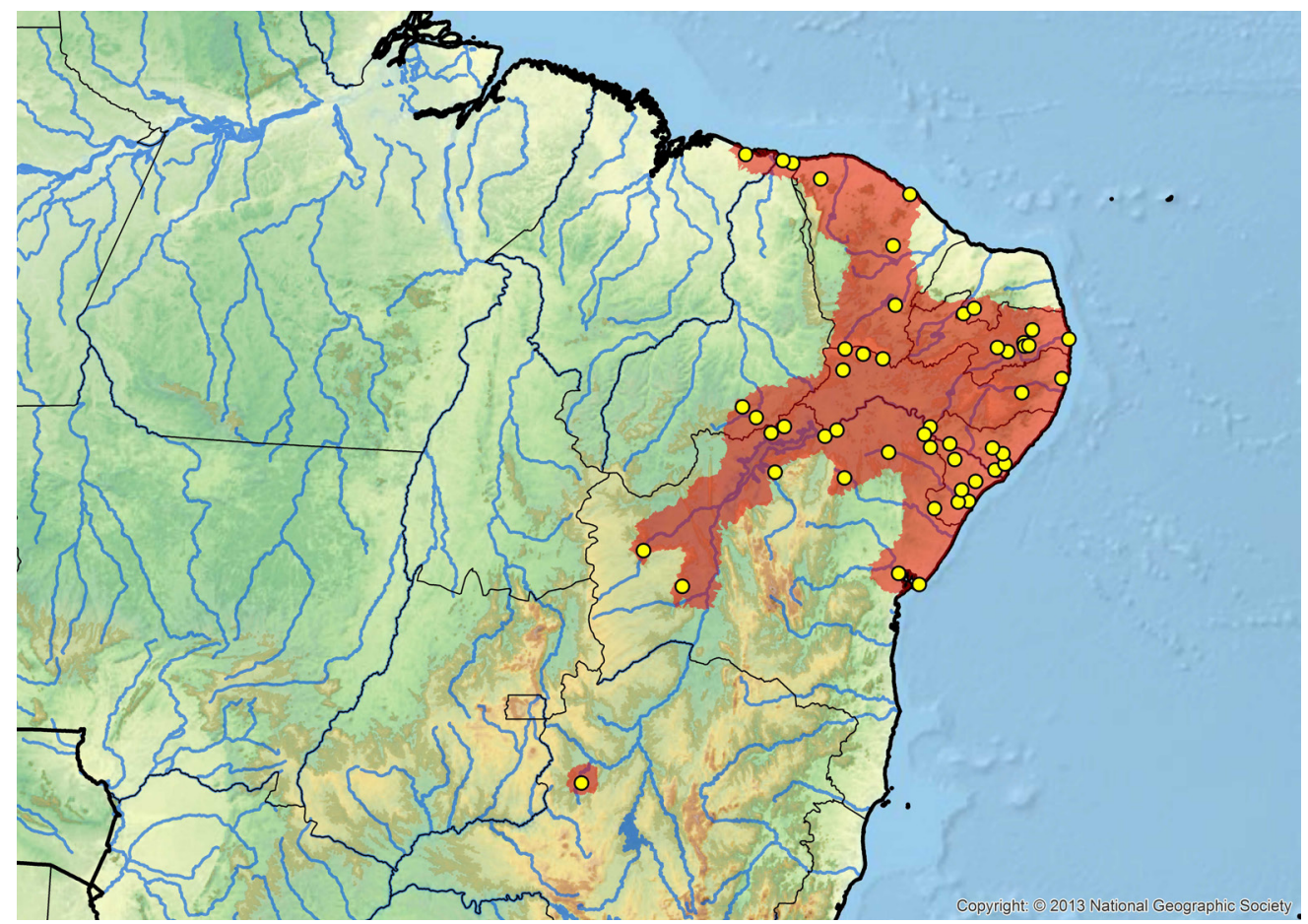

Figure 5. Distribution of Mesoclemmys tuberculata in northeastern Brazil. Yellow dots = museum and literature occurrence records of native populations based on Iverson (1992), plus more recent and authors' data. Red shading = projected historic distribution of $M$. tuberculata. Distribution based on GIS-defined level 10 HUCs (hydrologic unit compartments) constructed around verified localities and then adding HUCs that connect known point localities in the same watershed or physiographic region, and similar habitats and elevations as verified HUCs (Buhlmann et al. 2009; TTWG 2014), and adjusted based on authors' subsequent data.

Diet composition and feeding behavior are poorly known for wild M.tuberculata, but it has been noted that the species is carnivorous and consumes earthworms, fish, and insects in captivity (Bonin et al. 2006). In crushed DOR specimens, fish operculi, mollusks, freshwater shrimp, and insects have been noted in the stomach contents (Moura, unpubl. data).

Population Status. - Mesoclemmys tuberculata is commonly encountered within its geographical distribution. The creation of reservoirs for water storage has provided useable habitat for M. tuberculata, but in view of the broad agricultural areas between these habitats, such populations may be reproductively isolated from each other. Studies on population structure and status surveys of M.tuberculata in both undisturbed and anthropogenic habitats are needed.

Threats to Survival. - The main threats to M.tuberculata are habitat degradation caused by deforestation due to cattle ranching and agriculture and hunting, and possible competition and disease from invasive exotic species such as Trachemys dorbigni, T. scripta scripta, and T. s. elegans (Santana et al. 2014; Moura et al. 2016).

The Atlantic Forest and Caatinga regions have a high degree of anthropogenic impact and relatively poor representation in protected areas (Leal et al. 2005; Tabarelli et al. 2005). The Atlantic Forest is included in the world biodiversity hotspots (Mittermeier et al. 1999), and is seriously threatened, being reduced to small and isolated fragments that represent only about $12 \%$ of its original distribution (Ribeiro et al. 2009). The semi-arid Caatinga biome has been identified as one of the world's major tropical wilderness areas (Mittermeier et al. 2002). However, inappropriate land use has caused serious environmental damage, accelerating the desertification process in the biome. In addition, this biome is poorly protected, with less than $1 \%$ of its area represented in strict protected areas (Leal et al. 2005).

Mesoclemmys tuberculata is consumed by human populations in the semi-arid regions of northeastern Brazil (Barbosa et al. 2007; Alves 2009; Barbosa and Barbosa 2011; Alves et al. 2012; Mendonça et al. 2014; Moura et al.2014) and is also used in popular medicines in the treatment of diseases such as rheumatism, thrombosis, bronchitis, diarrhea, bleeding, asthma, sore throat, and hoarseness (Marques 1995; Costa-Neto 1996; Alves 2009; Alves et al. 2012; Mendonça et al. 2014). When incidentally captured in fishnets, it can be used as a food resource, as a medicine, or can be sold as a pet, but it is often discarded by local people (Alves et al. 2012; Mendonça et al. 2014).

Conservation Measures Taken. - The species is not listed on the IUCN Red List or CITES (Convention on International Trade in Endangered Species of Wild Fauna and Flora) nor on the Brazilian National List of Endangered Species, where it is considered as Least Concern. It was assessed as Least Concern by the IUCN SSC Tortoise and Freshwater Turtle Specialist Group in 1996, and Data Deficient in 2011 (TTWG 2011). 

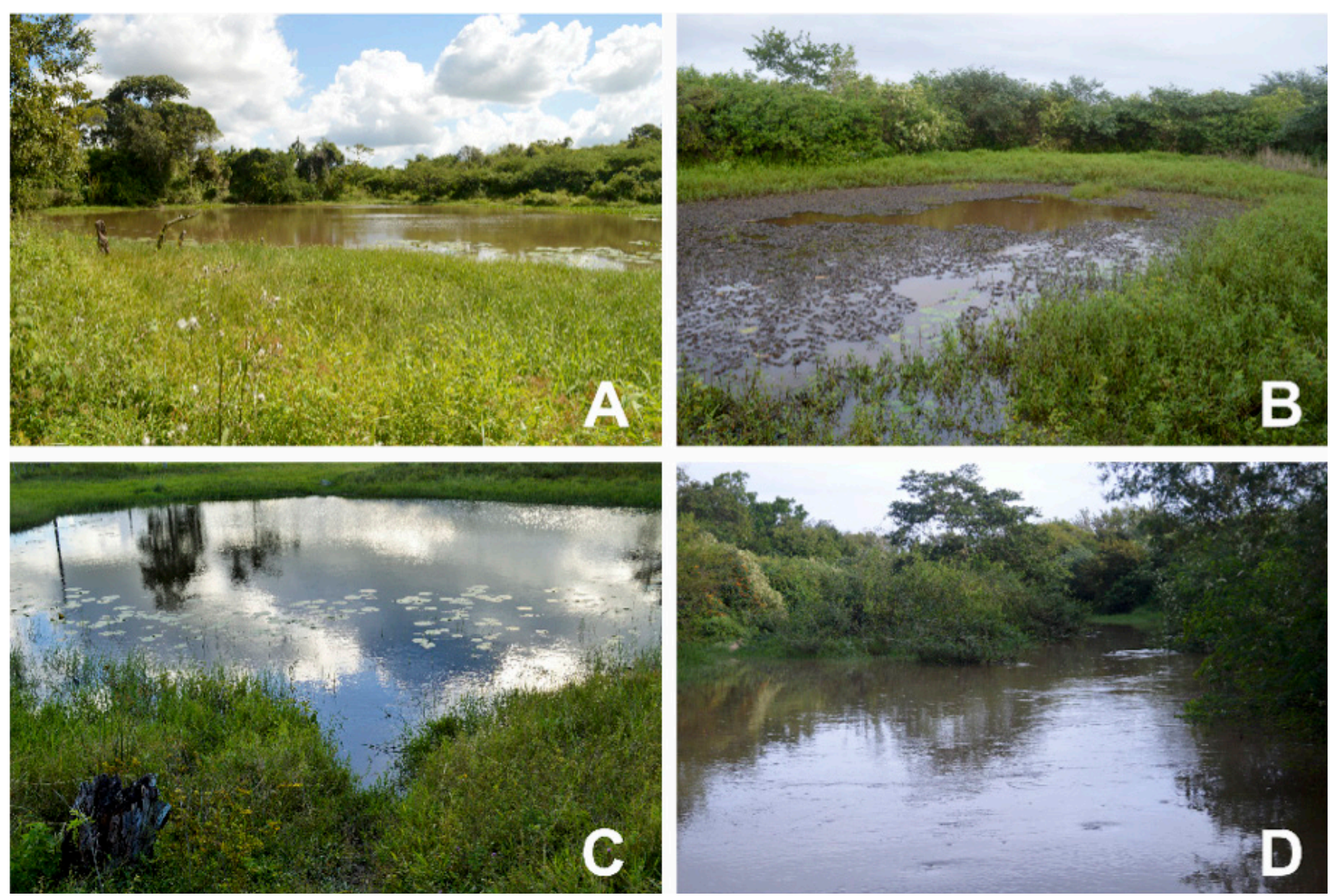

Figure 6. Habitats used by Mesoclemmys tuberculata. (A) Larger water body in the Atlantic Forest, Itabaiana, Sergipe, Brazil; (B) temporary lake with aquatic vegetation; (C) perennial lake; and (D) temporary streams in the Caatinga, Tobias Barreto, Sergipe, Brazil. Photos by Daniel O. Santana.

The species occurs in several protected areas in Brazil, including Parque Nacional de Ubajara, Reserva Particular do Patrimônio Natural Serra Grande, Área de Proteção Ambiental do Complexo do Planalto da Ibiapaba and Área de Proteção Ambiental da Chapada do Araripe in Ceará (Loebmann and Haddad 2010; Moura et al. 2015), Parque Nacional Serra da Capivara in Piauí (Cavalcanti et al.2014), Monumento Natural do São Francisco in Bahia, Sergipe and Alagoas (Santos et al. 2008), Refúgio de Vida Silvestre Mata do Junco Mata do Junco, Monumento Natural Grota do Angico, Parque Nacional Serra de Itabaiana in Sergipe (Morato et al. 2011; Santana et al. 2015), Refúgio de Vida Silvestre Mata do Camucim, Refúgio de Vida Silvestre Mata do Toró, and Estação Ecológica do Tapacurá in Pernambuco (Moura et al. 2011), and Estação Ecológica do Seridó in Rio Grande do Norte (Caldas et al. 2016). These areas are relatively small compared to the species'overall distribution; however, there are a significant number of conservation areas that provide protection to its populations, and the species probably also inhabits other unsampled protected areas.

Conservation Measures Proposed. - No specific conservation measures are considered immediately necessary, but the lack of adequate population status and life history studies for the species is a major limitation for proposing po- tential conservation measures for M.tuberculata. Therefore, there is a need for long-term ecological studies to evaluate its population status and possible threats.

Captive Husbandry. - Reproductive data for M. $t u$ berculata are from captivity at the São Paulo Zoo (Corazza and Molina 2004b), where a group of adults was kept in natural air temperatures between 6 and $35^{\circ} \mathrm{C}$ with water temperatures between 20 and $28^{\circ} \mathrm{C}$. Adults were fed mainly with red meat, fish, bone meal and, sporadically, flour beetle larvae and newborn mice. Mating was observed on several occasions, from January to October, and a single egg was recorded in October. Marques (2009) evaluated captive behavior of M. tuberculata, observing three individuals (two males and one female) kept in a small artificial pond with a fallen trunk and two artificial terrestrial shelters. The males spent most of their time using the shelters, while the female demonstrated territorial behavior and spent most of its time in the pond. The species was noted by Alves et al. (2012) to be used as a pet in the semiarid region of northeast Brazil, but no detailed information was provided.

Current Research. - Santana and collaborators are analyzing population structure, reproduction, morphometric aspects, diet, and parasites of M.tuberculata in the Caatinga and Atlantic Forest areas of Sergipe. Moura and collaborators 
are studying ecology, demography, parasites, morphometric aspects, home range, and genetic heterogeneity in freshwater turtles, including $M$. tuberculata, in Pernambuco and Alagoas. However, further research is needed to investigate basic biological aspects of this species, mainly in natural environments.

Acknowledgments. - Santana is supported by a fellowship from The Conselho Nacional de Desenvolvimento Científico e Tecnológico (CNPq); Marques is supported by a fellowship from São Paulo Science Foundation [grant 2013/11032-0, São Paulo Research Foundation (FAPESP)]. Santana thanks CNPq for his research fellowship.

\section{LITERATURE CITED}

Alves, R.R.N. 2009. Fauna used in popular medicine in Northeast Brazil. Journal of Ethnobiology and Ethnomedicine 5:1-30.

Alves, R.R.N., Pereira Filho, G.A., Vieira, K.S., Souto, W.M.S., Mendonça, L. E. T., Montenegro, P.F.G.P., Almeida, W.O., AND VIEIRA, W.L.S. 2012. A zoological catalogue of hunted reptiles in the semiarid region of Brazil. Journal of Ethnobiology and Ethnomedicine 8:1-29.

Barbosa, A.R., Nishida, A.K., Costa, E.S., AND CaZÉ, A.L.R. 2007. Abordagem etnoherpetológica de São José da Mata - Paraíba Brasil. Revista de Biologia e Ciências da Terra 7(2):117-123.

Barbosa, J.A.A. AND Barbosa, R.K.V.C. 2011. Percepção de moradores do semi-árido paraibano sobre a diversidade e relevância da fauna em duas comunidades rurais. Revista de Biologia e Ciências da Terra 11(1):123-133.

Barreto, L., Ribeiro, L.E.S., Ribeiro, A.B.N.,Azevedo, R.R., TAVARES, D.L., Abreu, J.M.S., AND CUTRIM, N.B. 2010. Mapeamento de áreas de ocorrência e aspectos de conservação de tartarugas (Chelonia) de água doce no Estado do Maranhão, Brasil. Boletim do Laboratório de Hidrobiologia 23(1):49-56.

Batistella, A., Pötter, C., Barreto, L., And Vogt, R. 2008. Geographic distribution: Mesoclemmys tuberculata. Herpetological Review 39(1):107-108.

BERRY, J.F. AND SHINE, R. 1980. Sexual size dimorphism and sexual selection in turtles (Order Testudines). Oecologia 44(2):185-191.

Bonin, F., Devaux, B., And Dupré, A. 2006. Turtles of the World. Baltimore: Johns Hopkins University Press, 416 pp.

Bour, R. 1973. Contribution à la connaissance de Phrynops nasutus (Schweigger: 1812) et Phrynops tuberculatus (Luederwaldt: 1926). Description d'une nouvelle sous-espèce originaire du Paraguay, Phrynops tuberculatus vanderhaegei (Testudinata Pleurodira - Chelidae). Bulletin de la Société Zoologique de France 98(1):175-190.

Bour, R. And Pauler, I. 1987. Identité de Phrynops vanderhaegei Bour 1973 et des espèces affines. Mésogée 47:3-23.

Bour, R. And Zaher, H. 2005. A new species of Mesoclemmys, from the open formations of northeastern Brazil (Chelonii, Chelidae). Papeis Avulsos de Zoologia 45:295-311.

Brito, E.S., Strüssmann, C., And Baicere -Silva, C.M. 2009. Courtship behavior of Mesoclemmys vanderhaegei (Bour, 1973) (Testudines: Chelidae) under natural conditions in the Brazilian Cerrado. Herpetology Notes 2:67-72.

Brito, E.S., Strüssmann, C., Kawashita-Ribeiro, R.A., Morais, D.H., Ávila, R.W., And Campos, V.A. 2012. New records and distribution extensions of three species of Mesoclemmys Gray,
1863 (Testudines: Chelidae) in Mato Grosso state, Brazil, with observations on terrestrial movements. Check List 8(2):294-297.

Buhlmann, K.A., Akre, T.S.B., Iverson, J.B., Karapatakis, D., MittermeIer, R.A.,GeOrges,A., Rhodin,A.G.J., vAn DiJK, P.P., AND GiBBons, J.W. 2009. A global analysis of tortoise and freshwater turtle distributions withidentification of priority conservation areas. Chelonian Conservation and Biology 8(2):116-149.

Bujes, C.S. 2010. Os Testudines continentais do Rio Grande do Sul, Brasil: taxonomia, história natural e conservação. Iheringia Zoologia 100(4):413-424.

Caldas, F.L.S., Costa, T.B., Laranjeiras, D.O., Mesquita, D.O., AND GARDA, A.A. 2016. Herpetofauna of protected areas in the Caatinga V: Seridó Ecological Station (Rio Grande do Norte, Brazil). Check List 12(4):1929.

Cavalcanti, L.B.Q., Costa, T.B., Colli, G.R., Costa, G.C., França, F.G.R., Mesquita, D.O., Palmeira, C.N.S., Pelegrin, N., Soares, A.H.B., Tucker, D.B., AND GardA, A.A. 2014. Herpetofauna of protected areas in the Caatinga II: Serra da Capivara National Park, Piauí, Brazil. Check List 10(1):18-27.

Chinen,S.,Lisboa, C.S., And Molina,F.B. 2004. Biologia reprodutiva de Hydromedusa tectifera em cativeiro (Testudines, Chelidae). Arquivos do Instituto Biológico 71:401-403.

Corazza, S.S. and Molina, F.B. 2004a. Biologia reprodutiva e conservação ex-situ de Bufocephala vanderhaegei (Testudines, Chelidae). Arquivos do Instituto Biológico 71:407-409.

Corazza, S.S. and Molina, F.B. 2004b. Biologia reprodutiva e conservação ex-situ de Batrachemys tuberculata (Testudines, Chelidae): primeiras observações.Arquivos do Instituto Biológico 71:410-412.

Costa, H.C. And BéRnILs, R.S. 2014. Répteis brasileiros: lista de espécies. Herpetologia Brasileira 3(3):74-84.

Costa-Neto,E.M. 1996. Faunistc resources used as medicines by an Afro-Brazilian community from Chapada Diamantina National Park, State of Bahia-Brazil. Sitientibus 15:211-219.

ERnst, C.H. AND Barbour, R.W. 1989. Turtles of the World. Washington, DC: Smithsonian Institution Press, $313 \mathrm{pp}$.

Forero-Medina, G., Castaño-Mora, O.V., CÁrdenar-Arevalo, G., AND Medina-RAnGEL, G.F.2013.Mesoclemmys dahli (Zangerl and Medem 1958) - Dahl's Toad-headed Turtle, Carranchina, Tortuga Montañera. n: Rhodin, A.G.J., Pritchard, P.C.H., van Dijk, P.P., Saumure, R.A., Buhlmann, K.A., Iverson, J.B., and Mittermeier, R.A. (Eds.). Conservation Biology of Freshwater Turtles and Tortoises: A Compilation Project of the IUCN/SSC Tortoise and Freshwater Turtle Specialist Group. Chelonian Research Monographs 5(1):069.1-8.

FREIBERG, M.A. 1981. Turtles of South America. Neptune, NJ:T.F.H. Publications, $125 \mathrm{pp}$.

FróEs, O.M. 1957. Notas quelonológicas. I) Atualizacão da nomenclatura dos quelônios brasileiros. Inheringia Zoologia 2:1-24.

GibBons, J.W. And Lovich, J.E. 1990. Sexual dimorphism in turtles with emphasis on the slider turtle (Trachemys scripta). Herpetological Monographs 4:1-29.

IvERSON, J.B. 1992. A Revised Checklist with Distribution Maps of the Turtles of the World. Richmond, IN: Privately Printed, 363 pp.

KInG, F.W. AND BuRKe, R.L. 1989. Crocodilian, Tuatara, and Turtle Species of the World: A Taxonomic and Geographic Reference. Washington, DC: The Association of Systematics Collections, 216 pp.

KrAmER,M.1995. Homerange of the Florida red-bellied turtle (Pseudemys nelsoni) in a Florida Spring Run. Copeia 1995(4):883-890.

LEAL, I.R., SiLVA, J.M.C., TABARELLI, M., AND LACHER JR., T.E. 2005. Changing the course of biodiversity conservation in the Caatinga of northeastern Brazil. Conservation Biology 19(3):701-706. 
Lins,E.,Martins Sobrinho,P.M.,AND Moura,G.J.B. 2015.Testudines da Reserva Madeiras. In: Moura, G.J.B., Nogueira, E.M.S., and Costa Neto,E.M. (Org.). Anfíbios e Répteis da Reserva Madeiras, Estado deAlagoas,Nordeste do Brasil(Vol.5).UEFS, pp.91-102.

LoEBmann, D. AND HADDAD, C.F.B. 2010. Amphibians and reptiles from a highly diverse area of the Caatinga domain: composition and conservation implications. Biota Neotropica 10(3):227-256.

Loebmann, D., MaI, A.C.G., And GarCia, A.M. 2006. Reptilia, Chelidae, Mesoclemmys tuberculata: geographic distribution extension. Check List 2(1):32-33.

LUEDERWALDT, H. 1926. Os chelonios brasileiros, com a lista das especies do Museu Paulista. Revista do Museu Paulista 14:405-468.

MARQues, J.G.W. 1995. Pescando Pescadores: Etnoecologia Abrangente no Baixo São Francisco Alagoano. São Paulo: NUPAUB-USP, $285 \mathrm{pp}$.

MARQUES,R.S.2009.Comportamento em cativeiro de Mesoclemmys tuberculata (Testudines: Chelidae). Anais do IX Congresso de Ecologia do Brasil, pp. 1-2.

Marques, T.S.,BöHM, S., Brito, E.S.,CABrera, M.R., AND Verdade, L.M. 2014. Mesoclemmys vanderhaegei (Bour 1973) - Vanderhaege's Toad-headed Turtle, Karumbé-hy. n: Rhodin, A.G.J., Pritchard,P.C.H., van Dijk, P.P., Saumure, R.A., Buhlmann, K.A., Iverson, J.B., and Mittermeier,R.A.(Eds.). Conservation Biology of Freshwater Turtles and Tortoises: A Compilation Project of the IUCN/SSC Tortoise and Freshwater Turtle Specialist Group. Chelonian Research Monographs 5(7):083.1-8.

McCord, W.P., JosePh-OUNI, M., AND LAMAR, W.W. 2001. A taxonomic reevaluation of Phrynops (Testudines: Chelidae) with the description of two new genera and a new species of Batrachemys. Revista de Biología Tropical 49(2):715-764.

MENDONÇA,L.E.T., VIEIRA, W.L.S., ANDALVES, R.R.N.2014.Caatinga ethnoherpetology: relationships between herpetofauna and people in a semiarid region of northeastern Brazil.Amphibian and Reptile Conservation 8(1):24-32.

Mertens, R. 1970. Zur Kenntnis von Phrynops nasutus. Senckenbergiana Biologica 51:17-20.

MÉTRAILLER, S. 2006. Ecologie de la Platémyde à grosse tête (Acanthochelys macrocephala) au Paraguay. Manouria 9(33):26-32.

MILAN,J.C. AND MELVIN,S.M.2001.Density, habitat use,movements, and conservation of spotted turtles (Clemmys guttata) in Massachusetts. Journal of Herpetology 35(3):418-427.

Miranda, A.F.J. AND SANTOS, E.M. 2008. Lista de serpentes e quelônios da Fazenda Saco - Serra Talhada/PE. Resumo em anal de congresso, JEPEX, edição eletrônica, Recife-PE.

Mittermeier, R.A., Robles-Gil, P., Hoffmann, M., Pilgrim, J., Brooks, T., Mittermeier, C.G., Lamoreux, J., and Fonseca, G.A.B. 1999. Hotspots: Earth's Biologically Richest and Most Endangered Terrestrial Ecoregions. Agrupación Serra Madre, SC, México: CEMEX, 430 pp.

Mittermeier, R.A., Mittermeier, C.G., Robles-Gil, P., Pilgrim, J., Fonseca, G.A.B., Brooks, T., AND Konstant, W.R. 2002. Wilderness: Earth's Last Wild Places. Agrupación Serra Madre, SC, México: CEMEX, 573 pp.

MoLina,F.B.1996. Mating behavior of captive Geoffroy's sidenecked turtles, Phrynops geoffroanus (Testudines: Chelidae). Herpetological Natural History 4(2):155-160.

Morato, S.A.A., Lima, A.M.X., Staut, D.C.P., Faria, R.G., SouZAAlves, J.P., GouveiA, S.F., AND ScupIN, M.R.C. 2011.Amphibians and reptiles of the Refúgio de Vida Silvestre Mata do Junco, municipality of Capela, state of Sergipe, northeastern Brazil. Check List 7(6):756-762.

Moura, C.C.M., Moura, G.J.B., Lisboa, E.B.F., And Luz, V.L.F. 2014. Distribuição geográfica e considerações ecológicas sobre a fauna de Testudines da Região Nordeste do Brasil. Sitientibus série Ciências Biológicas 14:1-20.

Moura, C.C.M., Moura, G.J.B., Chaves, L.D.S., Muniz, S.L.D.S., VEGA, E.S.F., AND JÚNIOR, V.E. 2015. Demography, sex ratio, and sexual dimorphism of Testudines in Araripe Bioregion, Ceará, Northeastern Brazil. North-Western Journal of Zoology 11: art.141514.

MouRA, G.J.B. 2010. Estrutura da comunidade de anuros e lagartos de remanescentes de mata atlântica,com considerações ecológicas e zoogeográficas sobre a herpetofauna do estado de Pernambuco, Brasil. Tese de Doutorado, Universidade Federal da Paraíba.

Moura, G.J.B., Freire, E.M.X., Santos, E.M., Lins, E., Andrade, E.V.E., AND CaValcante, J.D. 2011. Distribuição geográfica e caracterização ecológicas dos répteis do Estado de Pernmabuco. In: Moura, G.J.B., Santos, E.M., Oliveira, M.A.B., and Cabral, M.C.C. (Org.). Herpetologia do Estado de Pernambuco (Vol. 1). Brasília: Ministério do Meio Ambiente, pp. 229-290.

Moura, G.J.B., Santos, E.M., And Freire, E.M.X. 2012. Os sauropsidas répteis da Estação Ecológica do Tapacurá.In: Moura,G.J.B., Azevedo Júnior,S.M., andEl-Deir,A.CA.(Org.).ABiodiversidade da Estação Ecológica do Tapacurá - Uma Proposta de Manejo e Conservação (Vol. 1). Recife: UFRPE, pp. 273-324.

Moura, G.J.B., SANTos, E.M., Sousa, J.M., AND Martins-Sobrinho, P.M. 2016. Mata Atlântica de Pernambuco: Herpetofauna ameaçada e estratégias de conservação. In: Feliz, C.A., Moura, G.J.B., Freitas, M.A., and Escarlate, F. (Eds.). Plano de Ação Nacional para a conservação da herpetofauna ameaçada da Mata Atlântica Nordestina. 1ed. (Vol. único), pp. 128-172.

NovelLi, I.A. AND SouzA, B.M. 2007. Análise descritiva do comportamento de corte e cópula de Hydromedusa maximiliani (Mikan, 1820) (Testudines, Chelidae) em laboratório. Revista Brasileira de Zoologia 9:49-56.

Ribeiro, M.C., Metzger, J.P., Martensen, A.C., Ponzoni, F.J., And HiRota, M.M. 2009. The Brazilian Atlantic Forest: how much is left, and how is the remaining forest distributed? Implications for conservation. Biological Conservation 142(6):1141-1153.

Rodrigues, M.T. 2003. Herpetofauna da Caatinga. In: Leal, I.R., Tabarelli, M., and Silva, J.M.C.P. (Eds.). Ecologia e Conservação da Caatinga. Recife: Editora da UFPE, pp. 181-236.

Santana, D.O., De-Carvalho, C.B., Rocha, S.M., Freitas, E.B., AND FARIA, R.G. 2014. Trachemys dorbigni (Duméril \& Bibron, 1835)(Testudines: Emydidae) recorded in an artificial pond in northeastern Brazil. Herpetology Notes 7:211-213.

Santana, D.O., Marques, T.S., Vieira, G.H.C., Faria, R.G., and MesquitA, D.O. 2015. Hatchling morphology of the Tuberculate Toadhead Turtle (Mesoclemmys tuberculata [Lüederwaldt, 1926]) from northeastern Brazil (Testudines: Chelidae). Herpetology Notes 8:407-410.

SAntos, F.J.M, PeÑA, A.P., AND Luz, V.L.F. 2008. Considerações biogeográficas sobre a herpetofauna do Submédio e da Foz do Rio São Francisco, Brasil. Estudos, Goiânia 35(1/2):59-78.

Silveira, A.L. and Valinhas, R. 2010. Primeiro registro de Mesoclemmys tuberculata (Reptilia, Testudines, Chelidae) em área de Cerrado no Estado de Minas Gerais, sudeste do Brasil. Biotemas 23(4):157-161.

SouZA, F.L. 2004. Uma revisão sobre padrões de atividade, reprodução e alimentação de cágados brasileiros (Testudines, Chelidae). Phyllomedusa 3(1):15-27.

SouZA,F.L. 2005. Geographical distribution patterns of South American side-necked turtles (Chelidae), with emphasis on Brazilian species. Revista Española de Herpetología 19:33-46.

SouZA, F.L. AND MarTins, F.I. 2009. Hydromedusa maximiliani (Mikan 1825) - Maximilian's Snake-necked Turtle, Brazilian 
Snake-necked Turtle. n: Rhodin, A.G.J., Pritchard, P.C.H., van Dijk, P.P., Saumure, R.A., Buhlmann, K.A., Iverson, J.B., and Mittermeier, R.A. (Eds.). Conservation Biology of Freshwater Turtles and Tortoises: A Compilation Project of the IUCN/SSC Tortoise and Freshwater Turtle Specialist Group. Chelonian Research Monographs 5(1):026.1-6.

SouZA,F.L.,Giraldelli, G.R., And Martins,T.A. 2006.Reproductive aspects of Brazilian side-necked-turtles (Chelidae). Boletín de la Asociación Herpetológica Española 17(1):28-34.

Tabarelli, M., Pinto, L.P., Silva, J.M.C., Hirota, M., and BedÊ, L. 2005. Challenges and opportunities for biodiversity conservation in the BrazilianAtlanticForest.Conservation Biology 19(3):695-700.

TTWG (TurTLE TAXONOMY WORKING Group) [VAN DiJK, P.P., IvERSON, J.B., ShafFer, H.B., Bour, R., AND Rhodin, A.G.J.]. 2011. Turtles of the world, 2011 update: annotated checklist of taxonomy, synonymy, distribution, and conservation status. In: Rhodin, A.G.J., Pritchard,P.C.H., van Dijk, P.P., Saumure, R.A., Buhlmann, K.A., Iverson,J.B., and Mittermeier, R.A.(Eds.).Conservation Biology of Freshwater Turtles and Tortoises: A Compilation Project of the IUCN/SSC Tortoise and Freshwater Turtle Specialist Group. Chelonian Research Monographs 5(4):000.165-242.

TTWG (Turtle Taxonomy Working Group) [Van Dijk, P.P., Iverson, J.B., Rhodin, A.G.J., ShafFer, H.B., AND Bour, R.]. 2014. Turtles of the world, 7th edition: annotated checklist of taxonomy, synonymy, distribution with maps, and conservation status. In: Rhodin, A.G.J., Pritchard, P.C.H., van Dijk, P.P., Saumure, R.A., Buhlmann, K.A., Iverson, J.B., and Mittermeier, R.A.
(Eds.). Conservation Biology of Freshwater Turtles and Tortoises: A Compilation Project of the IUCN/SSC Tortoise and Freshwater Turtle Specialist Group. Chelonian Research Monographs 5(7):000.329-479.

VAnZolini,P.E.,Ramos-Costa,A.M.M.,AND Vitt,L.J.1980.Répteis das Caatingas. Rio de Janeiro. Academia Brasileira de Ciências, $161 \mathrm{pp}$.

VetTer, H. 2005. Turtles of the world. Vol 3. Central and South America: Edition Chimaira.

VinKe, T. AND Vinke, S. 2008. Die Pantanal-Plattschildkröte, Acanthochelys macrocephala, erobert den Dornbuschtrockenwald. Schildkröten im Fokus 5(1):22-31.

Zangerl, R. ANd Medem, F. 1958. A new species of chelid turtle, Phrynops (Batrachemys) dahli, from Colombia. Bulletin of the Museum of Comparative Zoology 119(5):373-390.

\section{Citation Format for this Account:}

Santana, D.O., Marques, T.S., Vieira, G.H.C., Moura, G.J.B., FARIA,R.G., AND MESQUTA, D.O.2016. Mesoclemmys tuberculata (Luederwaldt 1926)-Tuberculate Toad-headed Turtle.In: Rhodin, A.G.J.,Iverson,J.B., van Dijk,P.P., Saumure, R.A.,Buhlmann,K.A., Pritchard,P.C.H., and Mittermeier,R.A.(Eds.). Conservation Biology of FreshwaterTurtles and Tortoises: ACompilation Project of the IUCN/SSC Tortoise and Freshwater Turtle Specialist Group. Chelonian Research Monographs 5(9):097.1-8. [doi:10.3854/ crm.5 .097.tuberculata.v1.2016; http://www.iucn-tftsg.org/cbftt/] 